$$
\text { MOL. } 20001120.0120
$$

QA:N/A

$10 / 19 / 00$

\title{
Hydrogeologic characteristics of faults at Yucca Mountain, Nevada
}

\section{By}

\section{Robert P. Dickerson}

\section{Introduction}

Yucca Mountain comprises a series of north-trending ridges composed of tuffs within the southwest Nevada volcanic field, $120 \mathrm{~km}$ northwest of Las Vegas, Nevada. These ridges are formed of east-dipping blocks of interbedded welded and nonwelded tuff that are offset along steep, mostly west-dipping faults that have tens to hundreds of meters of vertical separation. Yucca Mountain is currently under study as a potential site for underground storage of high-level radioactive waste, with the principle goal being the safe isolation of the waste from the accessible environment. To this end, an understanding of the behavior of ground-water flow through the mountain in the unsaturated zone and beneath the mountain in the saturated zone is critical. The percolation of water through the mountain and into the ground-water flow system beneath the potential repository site is predicated on: 1) the amount of water available at the surface as a result of the climatic conditions, 2) the hydrogeologic characteristics of the volcanic strata that compose the mountain. and 3) the hydrogeologic characteristics of the structures, particularly fault zones and fracture networks, that disrupt these strata. This paper addresses the hydrogeologic characteristics of the fault zones at Yucca Mountain, focusing primarily on the central part of the mountain where the potential repository block is located.

\section{Faults as hydrogeologic elements}

Faults can affect the flow of ground-water in the saturated zone and the percolation of water through the unsaturated zone in two ways: 1) faults offset volcanic strata. locally juxtaposing units with different hydrologic properties against one another, and 2) fault zones exhibit characteristics that are different from surrounding unfaulted rocks and can act as both barriers to and conduits for ground-water flow. Data indicate that densely welded tuffs at Yucca Mountain may act as transmissive zones because of 
the pervasive cooling and tectonic fractures characteristic of these units, whereas nonwelded and altered tuffs act to retard or restrict flow. ${ }^{1}$

The various tuffs at Yucca Mountain decrease in thickness from north to south. For example, nonwelded and bedded tuffs between the densely welded Tiva Canyon and Topopah Spring Tuffs range from 75 meters thick in the northern part to 20 meters thïck in the southern part. ${ }^{2}$ Consequently, faults with greater offset are required to juxtapose these welded and nonwelded tuffs across faults in the northern part Yucca Mountain than in the southern part of the mountain. Similarly, the nonwelded and altered tuffs of the Calico Hills Formation underlying the Topopah Spring Tuff are thicker in the northern part of Yucca Mountain than in the southern part, and would likewise require larger faults to separate these strata in the northern part of the mountain.

Typically, faults in the study area are zoned into (1) a protolith of relatively undamaged rock that constitutes the fault block, (2) a damage zone of brecciated rock, and (3) and a fault core composed of gouge or a polished fault surface. Both fault core zones that lack gouge, and damage zones of brecciated rock can act as channels for fluid

flow. In contrast, core zones dominated by gouge can act as barriers to flow. ${ }^{3}$ Alteration and mineral precipitation can further alter the hydrogeologic characteristics of a fault zone by occluding pore space and filling connected fractures. Hydrologic data indicate that some combination of fault zone hydrogeologic characteristics and offset of strata, as discussed above, have effected the potentiometric surface across the Solitario Canyon Fault at Yucca Mountain. ${ }^{4.5}$

\section{Architecture of faults at Yucca Mountain}

Faults at Yucca Mountain can be categorized as block-bounding normal faults, intrablock normal faults, and strike-slip faults. Generally block-bounding faults accommodated the westward extension of Yucca Mountain and Crater flat, the smaller intrablock faults accommodated local intrablock strain, and strike-slip faults accommodated the northwest-striking dextral shear associated with the Walker Lane. Block-bounding faults are typically 20 to $35 \mathrm{~km}$ long, manifest the largest offset (on the order of 100's of meters of vertical separation), and have curviplanar fault surfaces with changes in fault strike and stratal dip across the fault. These faults dip westward at 
angles that vary from 80 to 40 degrees, splay into numerous fault strands, and exhibit hanging wall grabens and areas of pervasive hanging wall brecciation. Block-bounding faults form composite deformation zones from 5 to $150 \mathrm{~m}$ wide that display diffuse boundaries between the fault zone and the protolith.

In contrast, intrablock faults are shorter (trace lengths of 1 to $11 \mathrm{~km}$ ), have smaller offsets (10's of meters of vertical separation), and dip more steeply (75-90 degrees) with planar fault surfaces exhibiting no change in stratal dip across the fault and less variability in fault strike. Intrablock faults also exhibit fewer and smaller associated fault splays, and don't contain hanging wall grabens or broad areas of hanging wall brecciation. Intrablock faults range in width from a few centimeters to a few meters, and have more discrete boundaries between the protolith and the damage zone. Both blockbounding and intrablock faults locally display zones that widen upward into frameworks of upward-splaying faults, and both types of faults display great lateral variability in along-strike offset, amount of brecciation, and number of subsidiary splays. ${ }^{6,7}$ Normal faults at Yucca Mountain are dominantly north-striking, with a subset of northweststriking normal faults that act as relay structures linking some block-bounding faults and transferring offset between them.

However, in northeastern Yucca Mountain there is a domain dominated by northwest-striking dextral strike-slip faults. ${ }^{7}$ These strike-slip faults are near vertical and contain horizontal slickensides, mullion structures, and Riedel-like shears that indicate right-lateral offset. The deformation along these faults is distributed across zones locally as wide as 75 meters. ${ }^{6.7}$ In some instances the deformation is distributed amongst numerous discontinuous fault splays that are kinematically linked by breccia zones. ${ }^{8}$ Apparent vertical separation of strata of a few meters across the strike-slip faults varies from down-to-the northeast to down-to-the southwest, and may result from a component of dip-slip movement, from apparent offset resulting from dipping beds sliding horizontally past one another, or both. ${ }^{6.7}$

Both intrablock and block-bounding faults at Yucca Mountain exhibit damage zones of fractured and brecciated rock. Damage zones associated with block-bounding faults are much more extensive than those associated with intrablock faults and variously contain subsidiary fault splays, highly fractured rock, and brecciated rock. Damage 
zones 100 and 150 meters wide are associated with the block-bounding Paintbrush Canyon and Windy Wash faults. respectively, whereas typical damage zones associated with intrablock faults are generally a meter or two wide. Damage zones associated with intrablock faults usually contain anastimozing zones of highly fractured rock and of brecciated rock; smaller intrablock faults exhibit only discontinuous breccia zones. The fault core of block-bounding faults commonly displays planar zones of matrix-supported breccia of very finely comminuted rock in a sandy to clayey matrix, and containing multiple polished planar slip surfaces. Block-bounding faults exposed in underground tunnels at Yucca Mountain exhibit fault cores containing breccia on the smaller Bow Ridge fault and clay-rich gouge on the larger Solitario Canyon fault. The fault cores of intrablock faults typically are breccia zones a few centimeters thick of finely comminuted rock but lacking clay-rich gouge, and bound by planar slip surfaces. Breccias in the fault cores of block-bounding faults are more thoroughly comminuted, with much smaller clast size and greater proportions of sand-, silt-, and clay-sized matrix material than breccias from intrablock fault cores. ${ }^{9}$ Fault zone breccias exposed at the surface contain calcite cement and silica cement, whereas fault breccias observed underground contain less cement, the majority of which is silica and clay.

\section{Other factors effecting the hydrologic characteristics of faults}

The areal distribution of faults at Yucca Mountain potentially affects the hydrology of the region because the amount of deformation at Yucca Mountain increases from north to south. This is manifested by the north to south increase in the number of faults, the amount of offset per fault, and the amount of hanging wall deformation on each fault. ${ }^{6.7,10}$ This results in an increase in the total volume of fractured and brecciated rock from north to south at Yucca Mountain, with an attendant increase in fracture dominated porosity and permeability.

The orientation of fault segments will also affect the degree and extent of damage zone development. Kinematic indicators. such as slickensides on fault slip surfaces, show that movement on the block-bounding faults was oblique slip to the southwest, and thus includes a vector component of left-lateral strike-slip movement. ${ }^{6,7,11}$ For these north-striking faults such movement yields transpression on southwest-striking fault 
segments (restraining bends), and transtension on northwest-striking fault segments (releasing bends). Transpression at the restraining bends is characterized at Yucca Mountain by an increase in the number of fault splays, including small reverse faults, and by more and larger breccia zones. Transtension at the releasing bends is characterized by an increase in arcuate southeast-striking normal faults, but not by an increase in the amount of fault-related breccia relative to north-striking fault segments. ${ }^{6.7}$ The mechanics of faulting yields distributed crush breccias at restraining bends and highdilation breccias at releasing bends; the latter breccias enhance fluid flow whereas the former do not. ${ }^{12}$

\section{Conclusion}

Faults at Yucca Mountain are hydrogeologic features that may affect groundwater flow by acting as barriers, conduits, and combined conduit/barriers, or by offsetting strata of different hydrologic characteristics. Faults vary both laterally and vertically in their physical characteristics, and probably in their hydrogeologic properties. In general intrablock faults may increase the potential for fluid flow by increasing bulk intrablock fracture porosity, whereas block-bounding faults, which vary more widely in their fault characteristics, may act locally to either enhance, impede, or channelize fluid flow. Faults at Yucca Mountain increase in both size and number towards the south, which tends to increase the potential for fluid flow. In addition. nonwelded tuffs, which may act to retard fluid flow, decrease in thickness to the south. Fault orientation may also affect the hydrologic characteristics of faults by creating a change in the hydro-mechanical properties of rocks at restraining bends from those at releasing bends.

\section{References}

1. Winograd. Isaac J., and Thordarson. William, 1975, Hydrogeologic and hydrochemical framework. south-central Great Basin. Nevada-California, with special reference to the Nevada Test Site: U.S. Geological Survey Professional Paper 712-C, p. 31-34, 43-45. 
2. Moyer, Thomas C., Geslin, Jeffrey K., and Flint, Lorraine E., 1996, Stratigraphic relations and hydrologic properties of the Paintbrush Tuff nonwelded (PTn) hydrologic unit, Yucca Mountain, Nevada: U.S. Geological Survey Open-File Report 95-397, 151p.

3. Caine, Jonathan Saul, Evans, James P., and Forster, Craig B., 1996, Fault zone architecture and permeability structure; Geology, vol. 24, no. 11, p. 1025-1028.

4. Tucci, Patrick, and Burkhardt, D.J., 1995, Potentiometric-surface map, 1993, Yucca Mountain and vicinity, Nevada; U.S. Geological Survey Water-Resources Investigations Report 95-4149, 15p.

5. Ferrill, D.A., Winterle. J.. Wittmeyer, G., Sims, D., Colton, S., and Armstrong, A., 1999, Stressed rock strains groundwater at Yucca Mountain, Nevada; GSA Today, vol. 9 , no. 5 , p. $1-8$.

6. Day, Warren C., Potter, Christopher J., Sweetkind, Donald, Dickerson, Robert P., and San Juan, Carma A., 1998. Bedrock geologic map of the central block area, Yucca Mountain. Nye County, Nevada; U.S. Geological Survey Miscellaneous Investigations Map I-2601, scale 1:6000.

7. Day, Warren C., Dickerson. Robert P.. Potter, Christopher J., Sweetkind, Donald, San Juan, Carma A.. Drake. Ronald M. II. and Fridrich, Christopher J., 1998, Bedrock geologic map of the Yucca Mountain area, Nye County, Nevada; U.S. Geological Survey Geologic Investigations Map I-2627, scale 1:24,000.

8. Potter. Christopher J., Dickerson. Robert P., and Day, Warren C., 1999, Nature and continuity of the Sundance fault. Yucca Mountain, Nevada; U.S. Geological Survey Open File Report 98-266, 16 p. 
9. Dickerson, Robert P., 1999, Fault characteristics and their implication for groundwater flow at Yucca Mountain, Nevada: Geological Society of America Abstracts with Programs, vol. 31, no. 7, p.A-114.

10. Scott, Robert B., 1990, Tectonic setting of Yucca Mountain, southwest Nevada, in Wernicke, B.P., ed., Basin and Range extensional tectonics near the latitude of Las Vegas, Nevada: Boulder Colorado, Geological Society of America Memoir 176, p. 251-282.

11. Simonds, F.W., Whitney, J.W.. Fox, K.F., Ramelli, A.R., Yount, J.C., Carr, M.D., Menges, C.M., Dickerson, R.P.. and Scott, R.B., 1995, Map showing fault activity in the Yucca Mountain area, Nye County. Nevada; U.S. Geological Survey Miscellaneous Investigations Series Map I-2520, scale 1:24,000.

12. Sibson, Richard H., 1986, Brecciation processes in fault zones: inferences from earthquake rupturing; PAGEOPH. vol. 124, nos. 1-2, p. 159-175. 